\title{
A Comparison of Manchu Shaman Culture and Indian Shaman Culture*
}

\author{
Yanhong Li \\ College of Foreign Languages and Literature \\ Jilin Normal University \\ Siping, China 136000
}

\begin{abstract}
Shaman culture has played an important role in the Manchu and Indian races in the process of civilization. Both Manchu Shaman and Indian Shaman belong to the panmonotheistic, nature worship, animal worship, plant worship, totem worship, and ancestor worship which coexist and are intertwined. However, because Manchus and Indians are based on their natural environment, social environment and their own way of life, they need to imagine and make up the spirit of the world, to have the nature of their own and psychological state attached to the gods, and each of them has set a ritual of worship of gods to show the relationship between man and spirit respectively, the forms are diverse and varied.
\end{abstract}

Keywords-Manchu Shaman culture; Indian Shaman culture; nature worship; totem worship

\section{INTRODUCTION}

Originated in the Primitive Clan society, Shaman culture is the essence of the world non-material culture, has rich connotation and deep historical origin, living in north Asia, Northern Europe and North America of many ethnic groups. Inherited a traditional culture system, Shaman Culture can reflect the ancient social history and culture of the precious "living fossil". The most prominent feature of Shaman culture is the nature worship, totem worship and ancestor worship, whose contents are rich and colorful, with notable national and regional characteristics. Although Shaman culture contents gather dirt and traces inevitably in the long history of the society, its mainstream is the accumulation of a nation's accumulated rich and splendid cultural wisdom and spiritual wealth in the long history of developing, which are the cultural footprints of human ancestors and all.

Over the past few centuries, Shaman culture has suffered a huge impact, which had ever faced to the situation of declining, and even disappearing in a period of time for various reasons. In the 60 s to $70 \mathrm{~s}$ of 20 th century, the more common view was that Shaman culture was an outdated tradition and a superstition. This recognition has changed since the 1980s. In recent years, with the promotion of the Universal Declaration on Cultural Diversity adopted by UNESCO in 2001 and the Convention for the Protection of Intangible Cultural Heritage, which was enacted in 2003, the

*This paper is research results of Jilin Province Social Science Fund project, "A Comparative Study on Indian Shaman Culture and Manchu Shaman Culture". Project number: [2017JD33].
Shaman culture is undergoing a revival in some countries or regions that has prevailed, involving the political, economic and cultural and medical aspects.

The word "Shaman" originates from the language of Tungus, and the religious form of the Shaman-centered ancient people, Tungus believed is naturally referred to as "Shamanism" and, for a period of time, refers to the religious beliefs peculiar to the people of North Asia and Siberia. In the discussion among Chinese and foreign scholars about "Shamanism is a phenomenon in the world or confined to a certain area", Shamanism materials from the Americas, Africa and Central Asia increasingly confirm the view that "Shamanism is a universal phenomenon in the world".

The Shaman belief and its culture are a worldwide phenomenon. The rich cultural form of the Chinese and American Shaman has both universal value reflecting the general law of Shamanism and distinct individuality value. It is particularly rare that when Shamanism in northeast Asia and other spread district has become a historical relic of today, American Indian Shaman culture and Chinese Manchu Shaman culture are still in a fresh form of inheritance, reviving, surviving in a specific way.

North American Indians and northern China have deep cultural origins and many common features, which are important reference frames for comparative studies. American Indian Shaman Culture and Chinese Manchu shaman culture, this living culture provides valuable academic resources for the study of Shaman Culture in the world and have practical significance and cultural history value for enriching the diversity of shaman culture in the world.

\section{The FEATURES OF MANCHU SHAMAN CUlture}

Manchu is one of the oldest nationalities in the northeastern region of China, with a long history of culture, whose origins can be traced back to the pre-Qin period, known as "Sushen" at that time. After that the title of Manchu also changed several times, called Yilou in the Han dynasty, called Wuji in period of Wei Jin dynasties, Mohe in the period of Sui and Tang dynasties, Nvzhen in the dynasties of Song, Liao, Jin. The northeast of China is the hometown of Manchu and the cradle of Manchu culture, and 
it forms the unique Manchu culture in the course of the evolution of national development.

In the development process of Manchu culture, Shaman culture has a very important position in it, in The Book of Jin, Tong Dian and History of Liao and Jin and other historical books, the Manchu Shaman culture are records in detail.

In the period of the Manchu people's development, their nation has formed its own belief system. Shamanism has entered the Manchu people's life in the period of "Sushen", and in these long years of developing, Shamanism has gradually evolved. The Manchu ancestors made a living by hunting and fishing, and worshipped nature and ancestors in the harsh conditions of survival, praying for peace and reproduction. The most distinctive feature is the belief that Shamans are the medium of communication between humans and gods. Through some archaeological research data, we can generally see some of the basic features of Shamanism at that time. Soul concept into the hearts of people can be known from the tomb of the Manchu ancestors of the burial site of a large number of buried objects. At that time, people worshipped nature, and there were various works of art related to natural things in the ruins. Perhaps, the sacrifice has already originated, otherwise there will not be all kinds of fish bones, animal bones founded. If the above is some inference, then with the development of Shamanism, these become the facts.

The Shaman of Yilou period is not like the early period of Sushen, when the economy has a big development, social life is increasingly rich, and Shamanism culture is no longer monotonous. First of all, since the male status is increasingly prominent in the process of making production and doing labor, male power consciousness gradually matured. In this kind of society, Shamanism also attaches more importance to the worship of male ancestors. Second, Yilou people advocate force. "Fierce" is the prevailing atmosphere at that time, meanwhile, Shamanism of the hero worship consciousness began to sprout. Moreover, Shaman was in charge of drugs, at that time Yilou people learn to use drugs, Shaman Pharmacy slowly developed.

In the Wei and Jin Dynasties, the title of Wuji appeared and replaced the former Yilou. During this period, Shamanism is mainly awe-inspiring animals. People thought that bears, Black leopard, wolf, all do not harm, people also dare not kill. Wuji people and the surrounding Xianbei people frequent exchanges, such as the Northern Wei Buddhist thought also has a little influence on Shaman culture.

The Mohe people in the period of Sui and Tang dynasties, due to the establishment of the Bohai regime, developed as a country more than 200 years. The economy was also quite developed, with agriculture, handicrafts, animal husbandry and so on. The copper ribbon ornaments in the tomb of Mohe in that period was found in large quantities. The nature of the copper band ornaments is the Shaman's ritual, the deceased's identity should be Shamans who has the funerary copper belt adorn. It seems that Shamanism still exists in this period. But at this time the Shamanism was hit by more exotic cultures than Wuji culture, and Shamanism was no longer as valued as before until the appearance of the Nvzhen people.

In the dynasties of Song, Liao, Jin, Yuan, Ming, Qing they have the title of the name Nvzhen. Jin dynasty was the development heyday of Shamanism. The establishment of the Jin Dynasty has greatly developed the Shamanism. At this time the Shaman has a high status in the country, and the Shaman has a wide range of functions, almost everything proficient. According to historical records, the diseases are not cured by medicine, people believed wizard who killed pigs and dogs to resist diseases, or sent patients to the mountain or valley to avoid the diseases. When people were sick they believed the Shaman but did not call the doctor. This is enough to be seen that the Shaman was very popular among the populace.

The establishment of the Qing Dynasty made Nvzhen Shamanism has its own temple in that the period. People can worship in their own temples. Although they have the place in which they were belonging, Shamanism was in the ruling class at that time, who controlled the frequent ritual of Shamanism, witchcraft is also banned. Shamanism is more or less displayed in every period of Manchu development, which reflects the strength of Shamanism's vitality. There must be a life value in such a religion, or it is in itself an interpretation of the value of life.

Any nation has its own totem culture and Manchu is no exception. Shaman Totem reveals the value of life. The Manchu totem is called "the Pillar". "The Pillar" in the Manchu language means "the pillar of Banji". Manchu totem species are also many, there are various animal image, including eagles, snakes, frogs, etc. and there are also plants image, with willow as the representative. Often a totem will have a variety of image fusion. People draw a totem to reflect their inner world, the pursuit of life, and people's life and mental outlook can be seen through a variety of totems at the time. Manchu Totem is mainly influenced by Shamanism, which is one of the factors that form its own unique style. For example, in Shaman culture, willow symbolizes the birth of life. In a variety of fairy tales, they often begins with the willow breeding life, if willow are flourishing life is endless; if willow have withered life may be unexpected. In this way, the symbolic willow has become one of the objects of caring. The consciousness of this brand in the life of Manchu people is reflected by the totem culture. In addition, totem styles are generally feminine curves rather than straight lines. This is influenced by the Shaman dance. Although the Shaman dance is not as soft as folk dance, it has its own vigorous, they all belong to the dance category, and the curve beauty is the core. Such as, in the dance, "Catch a drum" of Manchu people, they mainly emphasize on "grasping the drum", but the posture of the drum grasping are very different, which can be divided into drumming, playing two drums, leaping to pass drum and so on. Such a brisk and cheerful dance, it can also be seen on the totem, which show the inherent vitality of Manchu culture. Totem is also very common in People's daily life, which can be seen in people's clothes, trousers, hats, jewelry and so on. A girl who loves beauty likes the bright totem of clothes; such clothes can make her mood joyful, which shows that they 
enjoy the life. An ambitious seven-foot tall man naturally likes the fierce animal totem, just like the Qing Emperor's clothes are painted full of dragons, that is his life consciousness, which shows that he can realize his ambitions, ideals, and highlight his life value. The totem culture reflects the Manchu culture and reflects the life value of Manchu culture.

Shaman sacrifice prevails in the history of the developing society, which profoundly embodies the social production mode and thought, reflects people's pursuit of the ideal life, pray for the gift of heaven, the pursuit of harmony between heaven and earth life. In real life, Manchu people's faith in Shaman is manifested in every aspect, for example, Manchu people held Shaman ritual, in order to obtain the blessing of worship and belief in the spirit when they celebrate the living, fertility, marriage and other aspects. Even the Shaman's beliefs added into Manchu art, such as: God song, dance, etc., fundamentally promote the development of Manchu art and culture. For Manchu people, Shaman faith is not a single religious belief, but the formation of a unique Shaman culture, with the development of the Times, the Shaman gradually evolved into a custom to inherit.

\section{THE FEATURES OF INDIAN SHAMAN CULTURE}

The cultural system of North American Indians, which was inherited by the North American Indians for generations and centered on the spiritual belief of all things, belongs to the broad-based Shaman culture, which historically was the root of the national culture of them. Since the 16th century, the North American Indians have suffered the double blow of genocide and cultural assimilation, and the Shaman culture has been hated and banned as the antithesis of "Christianity". Since 19th century, the rapid popularization of industrial civilization in the world, the decline of the North American Indian Shaman culture has accelerated. However, in recent years, in the process of North American Indians expressing their willingness to resist assimilation, Shaman culture has been restored and revitalized as the root of national culture.

The religious belief of the Indians belongs to the spiritual worship of all things, and is closely connected with the nature, the Earth, the sun, the moon and even the animals and plants which have spiritual strength. The supremacy of all things is the source of their faith, which has different names in different tribes. Shamanism is the core of the Indian religious belief, which maintains a strong vitality in the North American Indian tribes in many forms.

Since ancient times, the Indian tribes have inherited myths about heaven and earth, the universe, and the origins of the tribes, almost all of which depict the same scenario: the human fathers were born underground, there was full of the darkness not light, and then they rose from the holes in the ground to the ground with the power of nature or God, and learned to live and cultivate, living in harmony with nature and began to live a real human life. In such a myth, there is almost a person who can enter the ground, arbitrarily transform between people and other organisms, and connect with all things of the universe without any restriction of the role of the emergence, he sometimes even play the role as the Earth and the creator of the nature. In the minds of the native Indians, they were saints, prophets, and "witch doctors" who were able to heal a sudden illness, and "Shaman" Who knew the universe and knowledge of heaven and earth.

In the 16th century, Europeans began to explore North America, and they found in almost all the tribes of the Indians that they were able to communicate with the gods in order to learn knowledge about life and serve their tribe. The Indian dance is not meaningless pastime, which is a kind of praise, worship form, experience mutual connection through the movement. Dancing is an art before the concept of art, for the Indians it is a necessary spiritual behavior, and must have sacrifices and pious reverence. When the Indians danced, the drums and carols filled the sky, both at ceremonies and at rallies, and all the senses were mobilized. A solemn dance is a prayer that opens the door to the universe, discovers the inner world, and thanks the creator for its gift. Most of the Indian tribes in North America hold the Sun Dance in the Ceremonies and celebrations. In the center of the Sun Dance site, erect a pole, representing the great God of the sun and water, the center of the pole hanging buffalo skulls, so that the Ceremonies and celebrations are full of mysterious atmosphere. The purpose of the canon is to seek the help of God of the sun and water and the Gods' blessing to the people. The person who participates in the canon cannot eat or drink water, expressing that they are suffering from heat and thirst. The participants are to combine their souls with God and pray for God to divide the wet and the dry and then gain the power to save the people through a combination of opposites. The Shaman occasionally jumps among the dancers, encouraging the dancers to attain their power to become the man of God, and also to pray for the healing of their tribe members and to keep the tribe in harmony and unity. They considered harmony and unity as a collective force of the tribe.

The worship of heaven and the Sun Dance Ceremony belong to nature worship. Nature can bring them happiness, but also bring them disaster. They can not explain the power of nature, thinking that nature has the same needs and emotions, so try to sacrifice, express their reverence for nature, please nature, and affect the will of nature, so that the nature can grant more blessing, and give less disaster.

The Indians also use animals extensively as a symbol of their tribe. In most North American Indian tribes, the eagle is the sacred symbol of the creator. They held an eagle's ritual, and they danced acting as eagle. The dancers' costumes, movements, and shadows projected on the earth represent soaring eagles. In their view, the eagle is the messenger sent by God. Eagle feathers are used in treatment to remove negative effects. The dancers' decorative feathers and fans made with eagles, their wings and tails which will add strength to the dancers. They believe that the eagle's body, including its feathers, is effective for the Shaman's mastery of power or the transfer of power to other dancers and viewers. There are also tribal Shamans who use their drums as symbols of horses. The Indian tribes of the plains, which regarded the white animals as symbols of the gods, made them associated with the ancestors of the Shaman. For 
example, in the Nevieux tribe's creation myth the Sun's glorious image appeared: "Wearing white clothing, riding a white horse with a white bridle, He conceived a woman who would change, and the beautiful woman was a small white buffalo. She imparted knowledge of tobacco and treatment to Oglarassouze. She often turned herself into a white buffalo, appearing in the ritual of the Shaman. Many stories tell of what she did with the dual appearance of heroes and villains. If someone had offended her, she would punish them. The Kwajita tribe carved their creation myth on the totem pole. The tall totem poles, as memorials, were erected as a visual image in the villages in the north-west coast where they lived. The totem pole also has another meaning, which represents the Shaman's concept of "axis of the Universe", "the Center of the World" and "Tree of Life".

\section{CONCLUSION}

Shaman culture has played an important role in the Manchu and Indian race in the process of civilization, is the earliest form to express their world outlook, philosophy of life and values in their respective ways, is the cradle to produce singing, dance, painting, sculpture, poetry, myth, and so on.

Both Manchu Shaman and Indian Shaman belong to the pan-monotheistic, nature worship, animal worship, plant worship, totem worship, and ancestor worship which are coexisted and intertwined. However, because they are based on their natural environment, social environment and their own way of life and needs to imagine and make up the spirit of the world, have the nature of their own and psychological state attached to the gods, and each set a ritual of worship of the gods to show the relationship between man and spirit respectively, so the form is diverse and varied.

Rich and colorful Shaman culture is showing a picture of folk customs, highlighting the simplicity of pure customs, bold national personality. The cultural traits of a nation are accumulated, and can be inherited, which shows its universal meaning. The process of historical progress is actually a process of scouring the sand, and the excellent things must have eternal aesthetic value. What is of national is of international. Shaman culture has a positive significance to the contemporary people who can understand traditional culture of the national minority (ethnic minority) and learn the performance of the diversity of national culture, for the ethnic minority (ethnic minority) to develop culture on the basis of the tradition, for the development of national cultural undertakings and prosperity of the world's national culture. Rescuing, excavating, protecting and inheriting Shaman's cultural relics are of great significance for the existence and development of human culture. At the same time, the comparative study of Manchu Shaman culture and Indian Shaman culture is helpful to promote the protection of traditional culture and cultural tradition and lay the foundation for cultural innovation.

\section{REFERENCES}

[1] Andrei A. Znamenski. The Beauty of the Primitive - Shamanism and Western Imagination. New York: Oxford University Press, 2007, 64-70.

[2] Fu Yuguang. Shamanism and Mythology. Shenyang: Liaoning University Press, 1990.

[3] Guo Shuyun. "A Review of the Abroad Studies on the Physiology and Psychology of Shaman”. Ethnic Study, 4 (2007) 91-100.

[4] Jordan Paper. Native North American Religious Tradition: Dancing for Life. Greenwood Publishing Group, Inc., 2007, 49

[5] Liu Xiaomong, Ding Yi Zhuang. Shamanism and Northeast Nationalities. Changchun: Jilin Education Press, 1990.

[6] Meng Huiying. "On the Historical Transition of Shamanism". Journal of Jilin Normal University (Humanities \& Social Science Edition), 4 (2016) 1-10.

[7] William S. Lyon. Encyclopedia of Native American Shamanism: Sacred Ceremonies of North America. California: ABC-CLIO, Inc 1998, XIV 